\title{
SISTEM PAKAR UNTUK MENDIAGNOSA PENYAKIT PADA IKAN HIAS AIR TAWAR DENGAN FUZZY INFERENCE SYSTEM
}

\author{
Rina Dewi Indahsari ${ }^{1}$, Dina Komar Lia $^{2}$ \\ ${ }^{1,2}$ STMIK ASIA Malang \\ e-mail: $\underline{\text { rinadewi@asia.ac.id }}^{1}$, $\underline{\text { crispie.2202@yahoo.co.id }}^{2}$
}

\begin{abstract}
ABSTRAK
Salah satu penyebab utama kegagalan kegiatan budidaya ikan adalah karena faktor penyakit.Munculnya gangguan penyakit pada budidaya ikan merupakan resiko biologis yang harus selalu diantisipasi. Munculnya penyakit pada ikan umumnya merupakan hasil interaksi kompleks/tidak seimbang antara tiga komponen dalamekosistem perairan yaitu inang (ikan) yang lemah, patogen yang ganas serta kulitas lingkungan yang memburuk. Pembudidaya ikan harus memperoleh informasi yang cepat terkait penyakit yang menjangkiti ikannya, serta cara penanggulangannya seperti apa. Dalam penelitian ini dibuat system pakar untuk mendiagnosa penyakit ikan hias dengan menggunakan media website, sehingga dapat digunakan setiap saat tanpa harus menemui dokter/pakarnya.Knowledge base melibatkan 23 gejala dan 5 penyakit yang umum pada ikan hias air tawar, dengan menggunakan decision table menghasilkan 20 Rule. Proses inferensi menggunakan fuzzy tsukamoto, pemodelannya memiliki 23 variabel input dan 1 variabel output. Masing-masing variabel input memiliki 3 himpunan dan variabel output memiliki 5 himpunan. Hasil implementasi menunjukkan bahwa sistem yang dibangun dapat memberikan hasil diagnosa dengan tingkat akurasi $85 \%$.
\end{abstract}

Kata Kunci :Sistem Pakar, Diagnosa Penyakit, Ikan Hias Air Tawar, Fuzzy Inference System

\begin{abstract}
One of the main causes of failure in aquaculture activities is due to disease factors. The emergence of disease disorders in fish farming is a biological risk that must always be anticipated. The emergence of diseases in fish is generally the result of complex / unbalanced interactions between the three components in the aquatic ecosystem, namely weak hosts (fish), malignant pathogens and deteriorating environmental quality. Fish cultivators must obtain fast information related to diseases that infect their fish, and how to deal with them. In this study an expert system was created to diagnose ornamental fish disease using the media website, so that it can be used at any time without having to see a doctor / expert. Knowledge base involves 23 symptoms and 5 diseases that are common in freshwater ornamental fish, using a decision table producing 20 Rule. The inference process uses the Tsukamoto fuzzy, the modeling has 23 input variables and 1 output variable. Each input variable has 3 sets and the output variable has 5 sets. The implementation results indicate that the system built can provide diagnostic results with an $85 \%$ accuracy rate.
\end{abstract}

Keyword :Expert System, diagnosis of disease, freshwater ornamental fish, Fuzzy Inference System

\section{PENDAHULUAN}

\subsection{Latar Belakang}

Perkembangan ikan hias di Indonesia mengalami kemajuan yang terus meningkat, terutama ikan hias air tawar asli Indonesia.Dari sekian banyak jenis ikan hias, tidak semuanya telah dapat dibudidayakan.Ikan hias cukup dikenal oleh masyarakat sebagai hiasan aquarium. Dalam menternakkan ikan hias harus diperhatikan bahwa masing-masing jenis mempunyai sifat dan kebiasaan hidup yang berbeda-beda, misalnya dalam cara pemijahan, bertelur ataupun menyusun sarangnya. Permasalahan utama yang dihadapi dalam usaha budidaya ikan hias air tawar adalah proses perkembangan dan kematangan telur induk ikan umumnya lambat, sumberdaya air kualitasnya rendah dan penyakit ikan yang menyerang.

Salah satu penyebab gagalnya kegiatan budidaya ikan ini adalah karena faktor penyakit.Munculnya gangguan penyakit pada budidaya ikan merupakan resiko biologis yang harus selalu diantisipasi. Munculnya penyakit pada ikan umumnya merupakan hasil interaksi kompleks/tidak seimbang antara tiga komponen 
dalamekosistem perairan yaitu inang (ikan) yang lemah, patogen yang ganas serta kulitas lingkungan yang memburuk.

Sistem pakar (expert system) merupakan bidang ilmu dari Artificial Intellegence yang menggabungkan basis pengetahuan dengan kesimpulan dan solusi.Sistem pakar bertindak sebagai seorang konsultan cerdas dalam suatu bidang keahlian tertentu yang mampu melakukan diagnosa dan memberikan saran seolah seperti seorang pakar. Berdasarkan masalah yang dihadapi para pembudidaya ikan hias air tawar maka digunakan sistem pakar untuk membantu pembudidaya ikan hias air tawar dalam melakukan identifikasi penyakit ikan hias air tawar. Pada sistem pakar ini akan memberikan kemudahan bagi siapa saja yang ingin mengaksesnya dan mampumemberikan informasi yang optimal baik kepada pembudidaya ikan hias air tawar maupun masyarakat awam. Pada kasus ini menggunakan bahasa pemrograman PHP dan database MySQL untuk implementasinya.

\subsection{Referensi}

\subsubsection{Sistem Pakar}

Sistem pakar merupakan bidang ilmu yang menggabungkan basis pengetahuan dengan kesimpulan dan solusi.Secara umum sistem pakar (expert system) adalah sistem yang berusaha mengadopsi pengetahuan manusia ke komputer, agar komputer dapat menyelesaikan masalah seperti yang biasa dilakukan oleh manusia.Sistem pakar bertindak sebagai seorang konsultan cerdas dalam suatu bidang keahlian tertentu yang mampu melakukan diagnosa dan memberikan saran seolah seperti seorang pakar (Kusumadewi, 2003).

Dengan sistem pakar ini, orang awam dapat menyelesaikan masalah yang cukup rumit yang hanya dapat diselesaikan dengan bantuan para ahli.Tujuan pengembangan sistem pakar sebenarnya bukan untuk menggantikan peran manusia, tetapi untuk mensubtitusikan pengetahuan manusia kedalam bentuk sistem, sehingga dapat digunakan oleh orang banyak.

\subsubsection{Metode Forward dan Backward Chaining}

Inferensi merupakan proses untuk menghasilkan informasi dari fakta yang diketahui atau diasumsikan. Inferensi adalah konklusi logis (logical coclusion) atau implikasi berdasarkan informasi yang tersedia. Dalam sistem pakar proses inferensi dilakukan dalam suatu modul yang disebut Inference Engine (Mesin Inferensi).
Inference Engine merupakan modul yang berisi program tentang bagaimana mengendalikan proses reasoning (Kusumadewi, 2003). Ada dua metode inferensi yang penting dalam sistem pakar, yaitu runut maju (forward chaining) dan runut balik (backward chaining).

a. Runut Maju (Forward Chaining) Runut maju berarti menggunakan himpunan aturan kondisiaksi. Dalam metode ini, data digunakan untuk aturan mana yang dijalankan, kemudian aturan tersebut dijalankan. Proses diulang sampai ditemukan suatu hasil. Metode inferensi yang melakukan penalaran dari suatu masalah kepada solusinya. Jika klausa premis sesuai dengan situasi (bernilai true), maka proses akan menyatakan konklusi. Hal ini dapat dilihat pada gambar 1 .

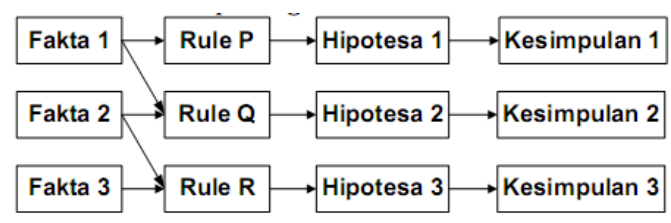

Gambar 1. Forward Chaining(Kusumadewi, 2003)

b. Runut Balik (Backward Chaining) Runut balik merupakan proses perunutan yang arahnya kebalikan dari runut maju. Proses penalaran runut balik dimulai dengan tujuan/goal kemudian menurut balik ke jalur yang akan mengarahkan ke goal tersebut, dimulai dari harapan apa yang akan terjadi (hipotesis) dan kemudian mencari bukti yang mendukung. Hal ini dapat dilihat pada gambar 2 .

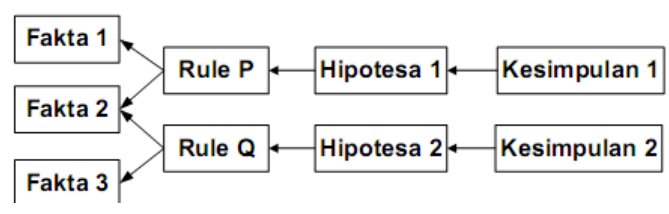

Gambar 2. Backward Chaining (Kusumadewi, 2003)

\subsubsection{Logika Fuzzy}

Logika fuzzy merupakan suatu cara yang tepat untuk memetakan suatu ruang input kedalam suatu ruang output. Logika fuzzy merupakan generalisasi dari logika klasik (Crisp Set) yang hanya memiliki dua nilai keanggotaan yaitu 0 dan 1 . Dalam logika fuzzy nilai kebenaran suatu pernyataan berkisar dari sepenuhnya benar sampai dengan sepenuhnya salah.

Teori himpunan logika fuzzy dikembangkan oleh Prof Lotfi A. Zadeh dari Universitas California 
pada tahun 1965.Ia berpendapat bahwa logika benar dan salah dari logika boolean tidak dapat mengatasi masalah gradasi yang berada pada dunia nyata. Untuk mengatasi masalah gradasi yang tidak terhingga tersebut, Zadeh mengembangkan himpunan fuzzy. Tidak seperti logika boolean, logika fuzzy mempunyai nilai yang kontinue. Fuzzy dinyatakan dalam derajat dari suatu keanggotaan dan derajat dari kebenaran, oleh sebab itu sesuatu dapat dikatakan sebagaian benar dan sebagaian salah pada waktu yang sama.

Kelebihan dari teori logika fuzzy adalah kemampuan dalam proses penalaran secara bahasa (Linguistic reasoning). Sehingga dalam perancangannya tidak memerlukan persamaan matematik dari objek yang akan dikendalikan.

\subsubsection{Fuzzy Inference System}

Fuzzy Inference System merupakan suatu kerangka komputasi yang didasarkan teori himpunan fuzzy, aturan fuzzy berbentuk if...then dan penalaran fuzzy. Mekanisme inferensi memiliki dua tugas utama yaitu:

1. Menentukan aturan yang paling sesuai dengan situasi terkini berdasarkan data yang dimasukkan.

2. Menggambarkan kesimpulan berdasarkan data masukan dan informasi pada rule-base.

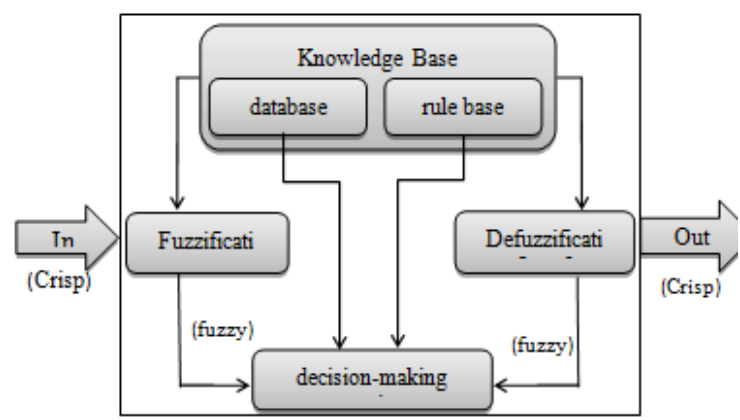

Gambar 3. Fuzzy Inference System

Pada Gambar 3 menunjukkan fuzzy inference system, terlihat bahwa fuzzy inference system terdiri atas lima blok yaitu rule-base yang berisi aturan fuzzy if...then, database yang menetapkan fungsi keanggotaan untuk himpunan fuzzy yang digunakan pada aturan fuzzy, decision making unit yang melakukan operasi inferensi pada aturan, fuzzification interface yang merubah input crisp menjadi fuzzy dengan derajat keanggotannya dan defuzzification interface yang merubah hasil sistem inferensi yang berupa fuzzy menjadi crisp sebagai keluaran terakhir.

\subsubsection{Fuzzy Tsukamoto}

Pada metode Tsukamoto, setiap konsekuen pada aturan yang berbentuk IF-THEN harus direpresentasikan dengan suatu himpunan fuzzy dengan fungsi keanggotaan yang monoton.Sebagai hasilnya, output hasil inferensi dari tiap-tiap aturan diberikan secara tegas (crisp) berdasarkan $\alpha$ predikat (fire strength).Hasil akhirnya diperoleh dengan menggunakan rata-rata terbobot.

Misal ada 2 variabel input, var-1(x) dan var-2(y) serta 1 variabel output var-3(z), dimana var-1 terbagi atas 2 himpunan yaitu A1 dan A2 dan var-2 terbagi atas himpunan B1 dan B2. Sedangkan var-3 juga terbagi atas 2 himpunan yaitu $\mathrm{C} 1$ dan $\mathrm{C} 2$. Ada dua aturan yang digunakan yaitu:

[R1] IF ( $\mathrm{x}$ is A1) and ( $\mathrm{y}$ is B2) THEN ( $\mathrm{z}$ is $\mathrm{C} 1$ )

[R2] IF ( $x$ is A2) and ( $y$ is B1) THEN ( $\mathrm{z}$ is $\mathrm{C} 2$ )
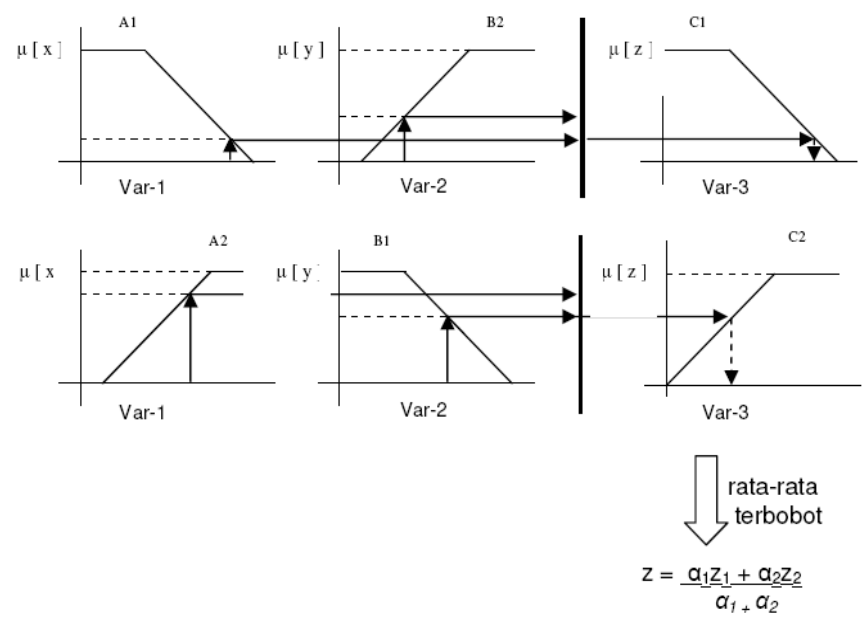

Gambar 4. Inferensi Penalaran Menggunakan Metode Tsukamoto

Setelah dilakukan proses implikasi nilai yang dihasilkan akan dikembalikan pada nilai tegas melalui defuzzifikasi yaitu dengan menentukan nilai $\mathrm{z}$ atau nilai tegas (crisp).

$$
\begin{gathered}
z=\operatorname{apread}_{1}{ }^{*} z_{1}+\operatorname{apread}_{2}{ }^{*} z_{2}+\ldots \ldots \ldots \operatorname{apread}_{n}{ }^{*} z_{n} \\
\operatorname{apread}_{1}+\operatorname{apread}_{2}+\ldots \ldots \ldots+\operatorname{apread}_{n}
\end{gathered}
$$

apread dihitung dari pengambilan nilai minimum penalaran fuzzy setelah dilakukan proses implikasi nilai yang dihasilkan akan dikembalikan pada nilai tegas melalui defuzzifikasi. Berdasarkan pada penegasan (defuzzy), proses ini merupakan suatu himpunan fuzzy yang diperoleh dari komposisi aturan-aturan fuzzy, sedangkan output yang dihasilkan merupakan suatu bilangan pada domain himpunan fuzzy tersebut.Metode tsukamoto sering digunakan pada kasus-kasus pendiagnosaan penyakit, pensimulasian, serta sistem pengambilan keputusan. 


\section{PEMBAHASAN}

Pada Tabel 1 dan Tabel 2 menunjukkan tabel yang berisi penyakit dan gejala yang diperlukan untuk mendeteksi penyakit yang diderita pada ikan hias. Data ini didapatkan dari pakarnya dan kemudian dikodekan agar mempermudah pembuatan sistem pakarnya.
Tabel 1. Kode Penyakit ikan hias air tawar

\begin{tabular}{|l|l|}
\hline Kode & \multicolumn{1}{|c|}{ Keterangan } \\
\hline P01 & White Spot (Ich) (Bintik Putih) \\
\hline P02 & Fin/TailRoot (Busuk Sirip / Ekor) \\
\hline P03 & Dropsy (Sisik Mengembung) \\
\hline P04 & Argulus (Kutu Ikan) \\
\hline P05 & Myxosporidiasis (Penyakit Gembil) \\
\hline
\end{tabular}

Tabel 2. Kode Gejala Penyakit ikan hias air tawar

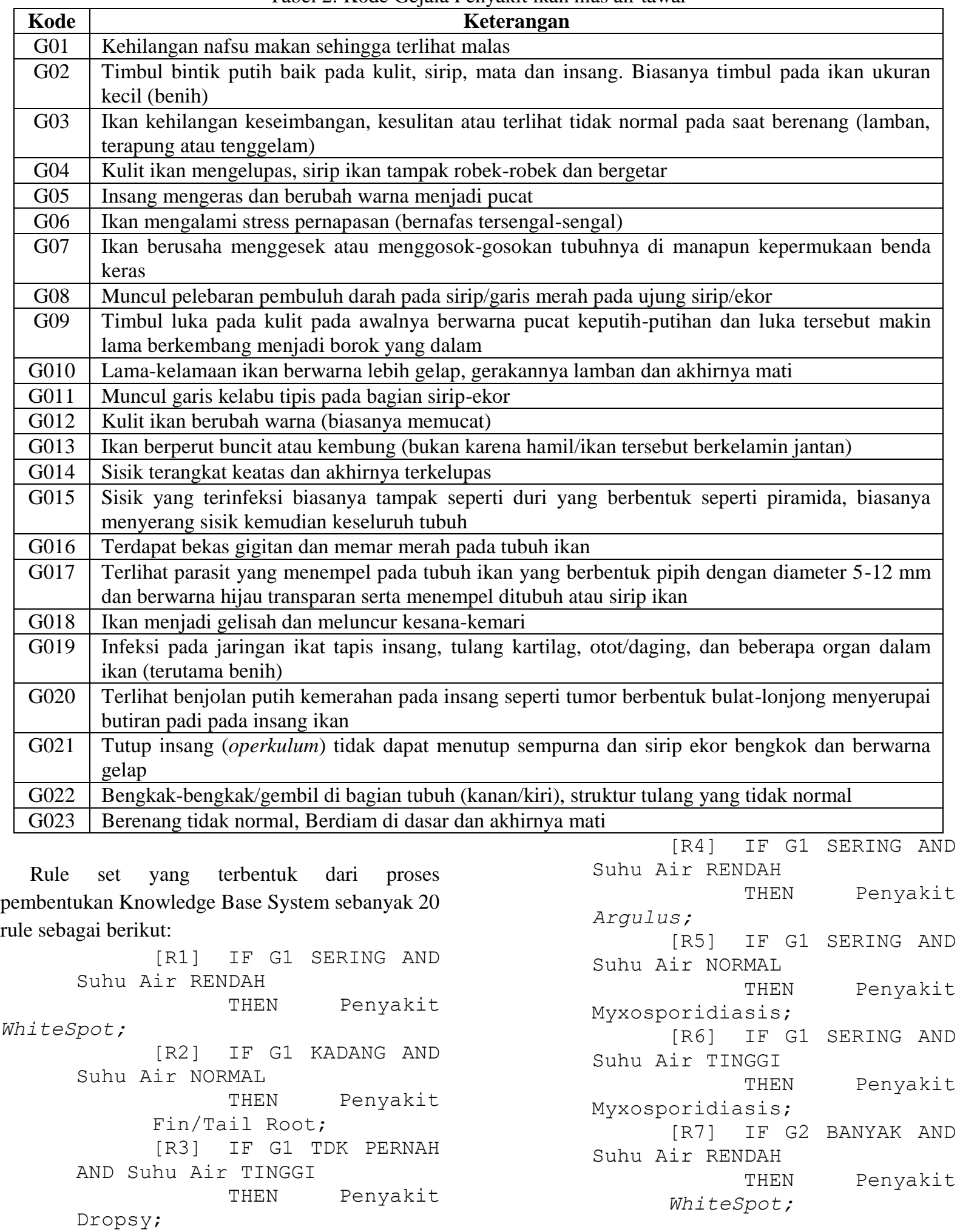




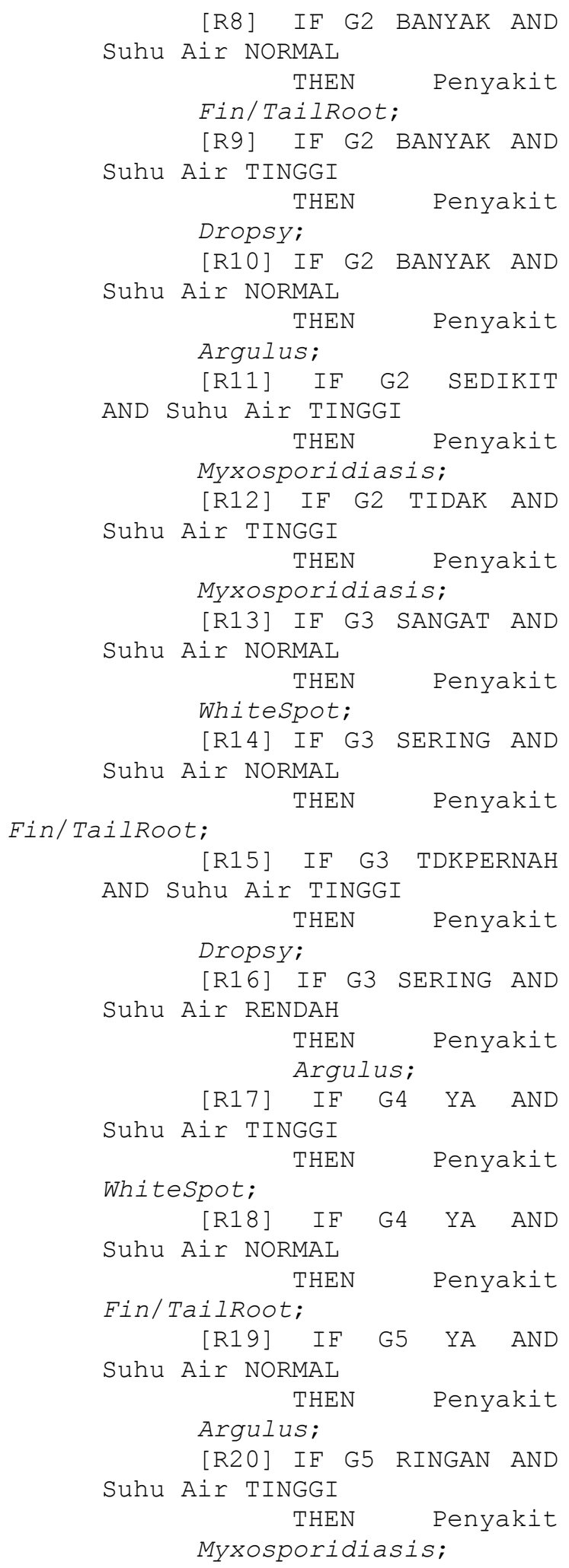

Perancangan Fuzzy Inference system meliputi proses fuzzyfikasi dan defuzzifikasi. Pembentukan variable dan himpunan sebagai berikut:

1. Variabel Gejala

Terdapat 23 gejala, setiap variabel gejala mempunyai 3 himpunan fuzzy. Himpunan TIDAK, RINGAN menggunakan pendekatan fungsi keanggotaan linier turun bahu kiri, himpunan
SERING, BANYAK, YA, AKUT, SANGAT dan PARAH menggunakan pendekatan fungsi keanggotaan linier naik bahu kanan, sedangkan himpunan KADANG, SEDANG, SEDIKIT, KRONIS, KEMBUNG, dan PUCAT menggunakan pendekatan fungsi keanggotaan berbentuk segitiga (Gambar 5).

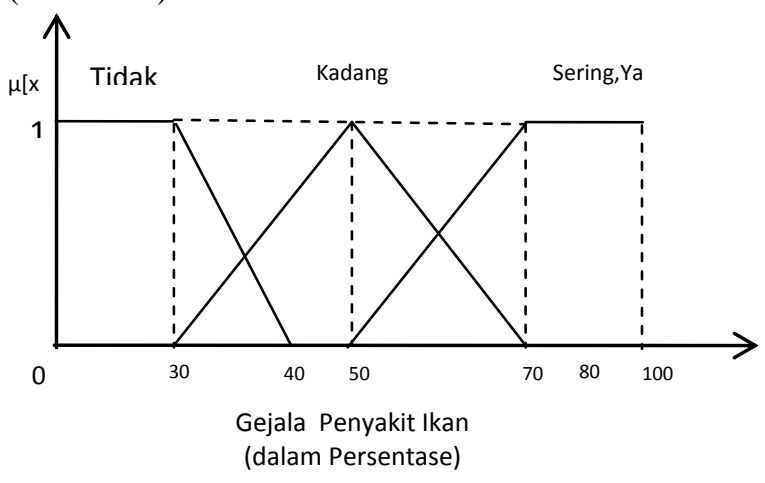

Gambar 5 Fungsi Keanggotaan Variabel Gejala

Fungsi keanggotaan himpunan SERING, YA, KADANG, SEDIKIT, TDK PERNAH dan TIDAK dapat dirumuskan pada persamaan dibawah ini :

$$
\begin{gathered}
\begin{array}{l}
\mu \text { TIDAK ADA, TDK } \\
\text { PERNAH }[x]=
\end{array} \begin{cases}1 ; & x \leq 0 \\
(x-0) /(20-0) ; & 0<x \leq 20 \\
(30-x) /(30-10) ; & 10 \leq x \leq 30 \\
0 ; & x \geq 30\end{cases} \\
\mu \text { KADANG, SEDIKIT }[x]= \begin{cases}0 ; & x \leq 30 \\
(x-30) /(50-30) ; & 30<x \leq 50 \\
(30-x) /(70-30) ; & 30 \leq x \leq 70 \\
0 ; & x \geq 70\end{cases} \\
\mu \text { SERING, YA }[x]= \begin{cases}0 ; & x<70 \\
(x-70) /(100-70) ; & 70<x \leq 90 \\
(70-x) /(100-60) ; & 70 \leq x \leq 100 \\
1 ; & x>100\end{cases}
\end{gathered}
$$

2. Variabel Penyakit

Fungsi keanggotaan pada variabel penyakit dapat dirumuskan pada persamaan berikut : 


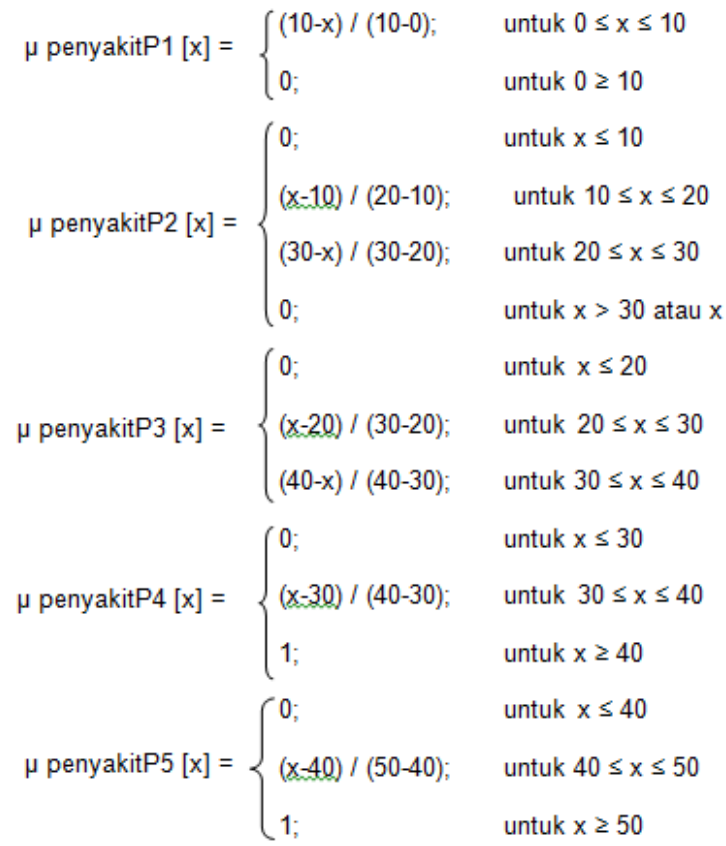

Fungsi keanggotaan :

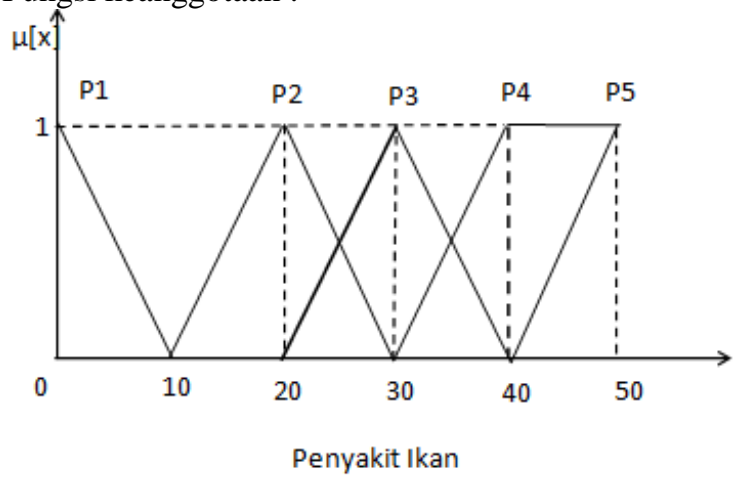

Gambar 6. Fungsi Keanggotaan Variabel Penyakit

Halaman utama berisi pilihan menu (link) yang dapat diakses oleh user.Pilihan menu tersebut terdiri dari home, admin, konsultasi, daftar penyakit dan tentang pembuat aplikasi. Tampilan menu utama dapat dilihat pada gambar berikut :

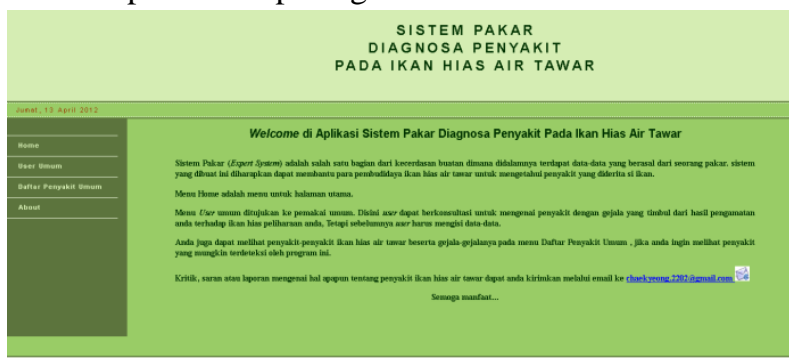

Gambar 7. Halaman Utama Sistem

Sebelum mulai berkonsultasi, user harus terdaftar dulu ke dalam sistem.Apabila telah terdaftar, maka user dapat melakukan login.

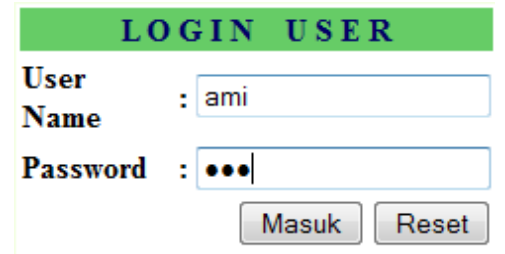

Masukkan user name dan password anda, Jika belum memiliki user name dan password silahkan mendaftar dahulu..!!

\section{$\underline{\text { Daftar }}$}

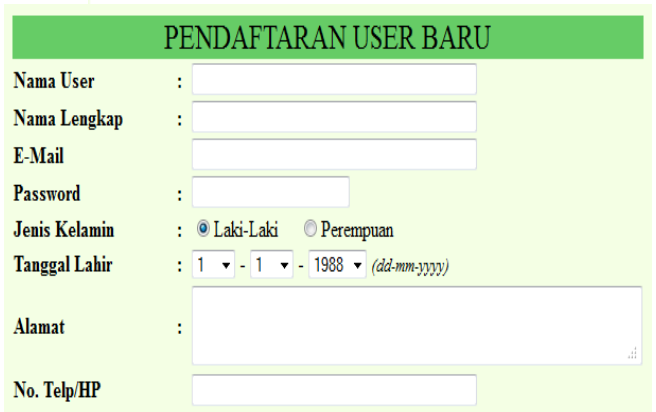

Gambar 8. Halaman Pendaftaran user dan login user

Setelah sukses melakukan login ke dalam sistem, akan ditampilkan halaman utama user. Untuk melakukan konsultasi dapat dipilih menu konsultasi. Pada halaman konsultasi, terdapat pertanyaan-pertanyaan gejala yang harus dijawab oleh user.

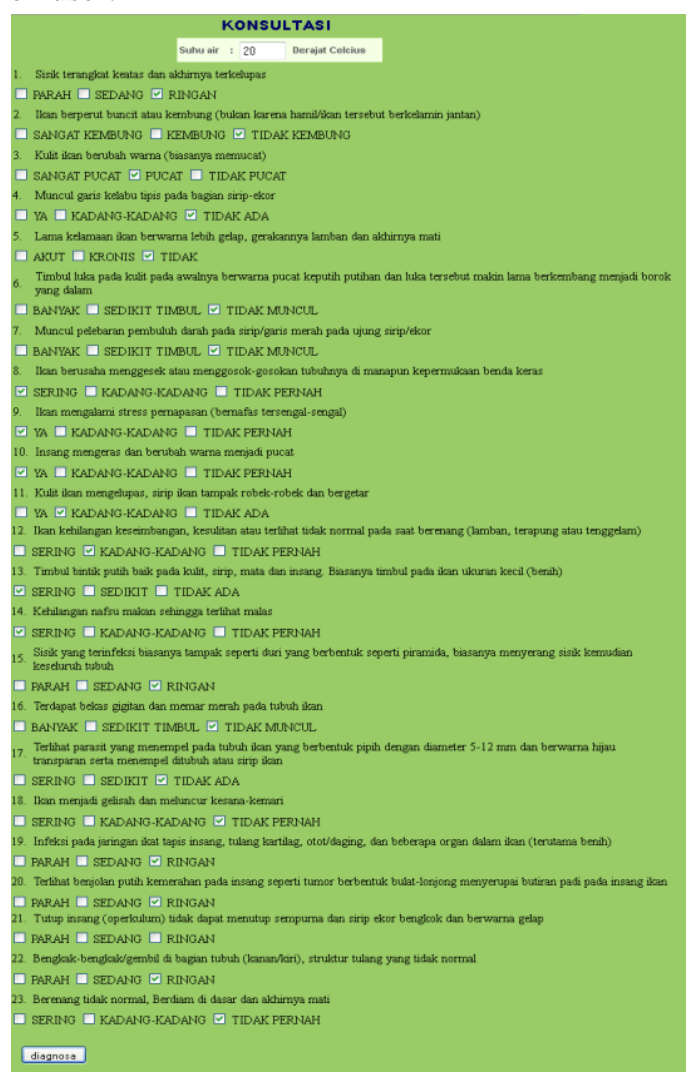

Gambar 9. Halaman Konsultasi 
Setelah pertanyaan pada halaman konsultasi dijawab, selanjutnya dapat dipilih tombol diagnose. Saat dipilih tombol diagnose, maka system akan melakukan proses inferensi menggunakan logika fuzzy metose Tsukamoto. Apabila gejala yang dimasukkan dikenali oleh system maka akan ditampilkan hasil diagnose seperti pada Gambar 10. Apabila gejala yang dimasukkan tidak dikenali oleh system, maka system tidak menampilkan hasil analisa dan diberikan keterangan "Tidak Terdefinisi" seperti ditampilkan pada Gambar 11.

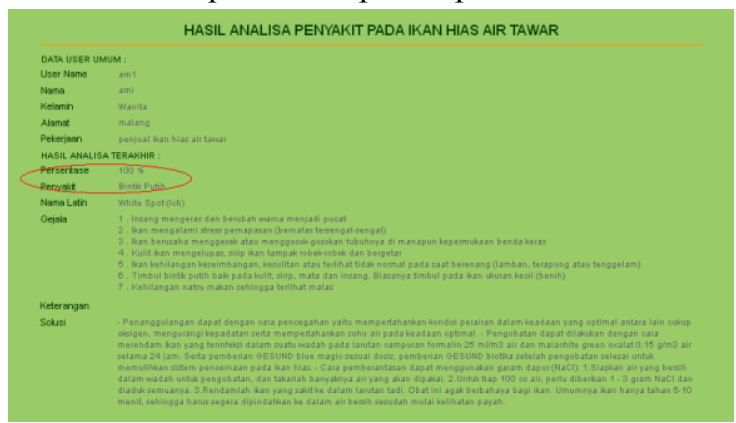

Gambar 10. Halaman Konsultasi

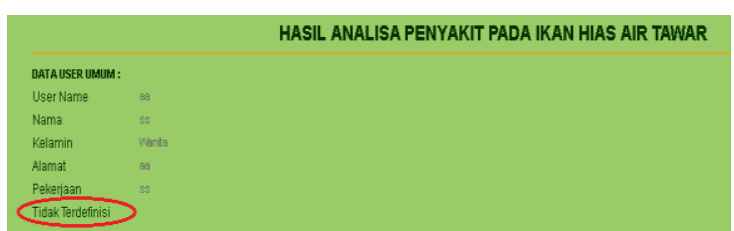

Gambar 11. Halaman Konsultasi

\section{KESIMPULAN}

Dari hasil penelitian dan pembahasan pada BAB sebelumnya dapat diambill beberapa kesimpulan sebagai berikut :

1. Dari proses KBS (Knowledge Based System) dengan gejala sebanyak 23 gejala dan 5 penyakit dihasilkan rule sebanyak 20, dimana rule tersebut digunakan dalam proses inferensi menggunakan metode Fuzzy Tsukamoto.

2. Untuk pendeteksian penyakit pada ikan hias air tawar dengan Fuzzy Tsukamoto tidak sepenuhnya efisien karena pada saat dilakukan pengujian tingkat keakuratan sistem sebesar $85 \%$.

\section{Saran}

Mengingat berbagai keterbatasan yang ada pada sistem ini, maka ada beberapa saran yang harus diterapkan guna pengembangan sistem lebih lanjut :

1. Pengembangan sistem pakar ini selanjutnya dapat memperluas penyakit yang dideteksi, karena begitu banyaknya sumber penyebab penyakit ikan hias air tawar yang ada.

2. Pengembangan pendeteksian penyakit ikan hias air tawar dapat digabung dengan berbagai disiplin ilmu artificial intelligent. Seperti, robotic, computer vision, speech recognition dan sebagainya.

\section{PUSTAKA}

Arhami, Muhammad. Konsep Dasar Sistem Pakar. Yogyakarta. Andi. 2005.

Faridl, Miftah. Fitur Dahsyat Sublime Text 3. Surabaya. LUG. 2015.

Jogianto, H. Analisa dan Desain Sistem Informasi, Pendekatan Terstruktur Teori dan Praktek Aplikasi Bisnis. Yogyakarta. ANDI. 2008.

Kendall dan Kendall. Analisis dan Perancangan Sistem Jilid 1Edisi Kelima. Jakarta. PT. Prenhalindo. 2003.

Kristanto, Andri. Kupas Tuntas PHP dan MySQL. Klaten. Cable Book. 2010.

Kusrini. Aplikasi Sistem Pakar. Yogyakarta. Andi. 2008.

Kusumadewi, S. Artificial Intelligence (Teknik dan Aplikasinya). Yogyakarta. GRAHA ILMU. 2003.

Sutojo, T. Mulyanto, E. Suharto, V. Kecerdasan Buatan. Andi. Yogyakarta. 2011.

Suwed, Muhammad A., Rodame, Napitupulu. Panduan Lengkap Kucing. Jakarta. Penerbit Penebar Swadaya. 2015 